\title{
Oxidative Stress Signalling in the Apoptosis of Jurkat T-Lymphocytes
}

\author{
Raffaella Chiaramonte, ${ }^{1 *}$ Enrico Bartolini, ${ }^{1}$ Patrizia Riso, ${ }^{2}$ Elisabetta Calzavara, ${ }^{1}$ Daniela Erba, ${ }^{2}$ \\ Giulio Testolin, ${ }^{2}$ Paola Comi, ${ }^{1}$ and Gajanan V. Sherbet ${ }^{3,4}$ \\ ${ }^{1}$ Department of Biomedical Sciences and Technologies, University of Milano, LITA-via Fratelli Cervi 93- \\ 20090 Segrate (MI), Italy \\ ${ }^{2}$ Department of Food Science and Microbiology, University of Milano, via Celoria 2- 20133 Milano, Italy \\ ${ }^{3}$ The Institute for Molecular Medicine, 15162 Triton Lane, Huntington Beach, California \\ ${ }^{4}$ Communications and Signal Processing Research Group, Department of Electrical and Electronic \\ Engineering, University of Newcastle upon Tyne, United Kingdom
}

\begin{abstract}
The pathways of transduction of oxidative stress signals have been studied using the Jurkat T cell model. The oxidative stress was induced by exposure of the cells to $100 \mu \mathrm{M} \mathrm{H}_{2} \mathrm{O}_{2}$. DNA damage was detected within 15 min after commencement of treatment. DNA damage repair occurred within about $1 \mathrm{~h}$ in cells exposed to oxidative stress for $15 \mathrm{~min}$. In continuous exposure to stress, DNA repair was slower and control levels of DNA integrity were not reached. DNA repair did not involve gene transcription. $\mathrm{H}_{2} \mathrm{O}_{2}$ at $100 \mu \mathrm{M}$ caused cell death by necrosis as well as by apoptosis. Both these processes were induced by $15 \mathrm{~min}$ exposure to the stress stimulus. However, some important differences were found between necrosis and apoptosis. Necrosis was more rapid, began within an hour of treatment and continued to increase during the full duration of the experiment. But apoptosis was seen after $4 \mathrm{~h}$ from treatment and was conspicuous between 6 and $20 \mathrm{~h}$ after the start of treatment. The necrotic phase preceded apoptosis, although these did show an overlap. In the necrotic phase, $B \mathrm{Cl}-2$, Caspase 8 genes were down regulated. The $6-20 \mathrm{~h}$ phase characterised by a marked increase in apoptosis is accompanied by the up regulation of both $\mathrm{BCl}-2$ and Caspase genes. Expression of the Fas and $p 53$ genes was not altered in either phase. We also analysed the levels of expression of the scavenging genes whose gene products are involved in detoxification. No modulation of the antioxidant enzymes, catalase, Cu/ $\mathrm{Zn}$ superoxide dismutase and glutatione peroxidase was detectable. J. Cell. Biochem. 82: 437-444, $2001 . \quad$ (c) 2001 Wiley-Liss, Inc.
\end{abstract}

Key words: leukaemia cells; apoptosis; oxidative stress signalling; apoptosis genes; DNA repair; antioxidant enzymes

Oxidative stress plays a prominent role in the functioning of the immune system both at physiological and pathological levels. Lymphocytes undergo continuous scrutiny to determine if they should be preserved or programmed to die and, recently, it has been suggested that oxidative stress may be a physiological mediator of apoptosis in lymphoid cells [Buttke and Sandstrom, 1995]. Actively replicating lymphocytes are particularly rich in poly-unsaturated

Grant sponsor: MURST to PC.

*Correspondence to: Raffaella Chiaramonte, Department of Biomedical Sciences and Technologies, University of Milano, LITA-via Fratelli Cervi 93- 20090 Segrate (MI), Italy. E-mail: raffaella.chiaramonte@unimi.it

Received 6 December 2000; Accepted 29 January 2001 (c) 2001 Wiley-Liss, Inc. fatty acids, which are a target of reactive oxygen species (ROS) [Goppelt-Strube and Resch, 1987]. Oxidative stress is known to be associated with reduced or abnormal immune function in ageing [Lieber, 1998], AIDS [Dobmeyer et al., 1997], diabetes [Dandona et al., 1996], smokingrelated pathologies [McAllister-Sistilli et al., 1998; Suzuki et al., 1999], and some autoimmune and inflammatory diseases [Frenkel et al., 1992; Cooke et al., 1997].

A judicious antioxidant supplementation has been reported to alleviate free radical-mediated damage [Duthie et al., 1996]. Therefore, we have attempted to elucidate the pathways of stress signal transduction by using a T-cell model, whose response to oxidative stress can be assessed by employing a set of well-defined criteria. In this work, we have used Jurkat cell line because they possess membrane markers that 
characterise normal T-lymphocytes [Konikova et al., 1992]. We have used hydrogen peroxide $\left(\mathrm{H}_{2} \mathrm{O}_{2}\right)$ as oxidative stimulus since it can permeate the plasma membrane and can be converted in the cell into more reactive oxygen intermediates. In order to obtain a full picture of the Jurkat cell response, we have examined different aspects of cell necrosis and apoptosis, namely the expression of apoptosis-associated genes, DNA damage and repair together with an analysis of expression of genes involved in DNA repair; the toxic effect of ROS, and the activation and expression of genes coding for free radical scavenging enzymes.

\section{MATERIALS AND METHODS}

\section{Cell Culture}

Jurkat $\mathrm{T}$ cells were grown and maintained in RPMI-1640 supplemented with $10 \%$ foetal calf serum. Cells growing exponentially were treated at a density of $5 \times 10^{5}$ cells $/ \mathrm{ml}$ with the desired $\mathrm{H}_{2} \mathrm{O}_{2}$ concentration.

\section{Necrosis Assay}

Necrosis was evaluated by Tryphan Blue vital staining performed on both cells left in $100 \mu \mathrm{M}$ $\mathrm{H}_{2} \mathrm{O}_{2}$ for the full duration of the experiment or pulsed with $100 \mu \mathrm{M} \mathrm{H}_{2} \mathrm{O}_{2}$ for 15 min and then placed in fresh medium until the end of the experiment. The experiments were performed over $20 \mathrm{~h}$ and samples analysed at different intervals. Data obtained by Trypan Blue vital staining were compared with propidium iodide (PI) nuclear staining.

\section{Apoptosis Assay}

Apoptosis was evaluated by changes in nuclear morphology observed with the double staining with Annexin V and PI, the experimental design being the same as that adopted for the necrosis assay. At the end of each experimental interval $3 \times 10^{5}$ cells were processed as described in the Annexin V-Fitch Apoptosis Detection Kit (MBL) instructions. Processed cells were placed on a microscope slide with a cover glass and then viewed under UV illumination on a Nikon fluorescence microscope.

\section{Determination of DNA Damage by Comet Assay}

Cells were maintained in $100 \mu \mathrm{M} \mathrm{H} \mathrm{H}_{2} \mathrm{O}_{2}$ or after $15 \mathrm{~min}$ of $\mathrm{H}_{2} \mathrm{O}_{2}$ treatment, were centri- fuged and incubated in fresh medium at $37^{\circ} \mathrm{C}$. DNA damage in control and $\mathrm{H}_{2} \mathrm{O}_{2}$ treated Jurkat cells was measured at various intervals using the alkaline comet assay as previously described [Riso et al., 1999]. Fifty cells for each slide were electronically captured and analysed for fluorescence intensity with a Comet Analysis programme (IFR, Norwich, UK) supported by the image-processing environment VISILOG 4 (Noesis, Orsay, Cedex, France). Relative Tail Moments (RTM) of treated cells and control cells were evaluated as follow: RTM = Tail Moment/ (Head + Tail Moment). Tail/Head Moment is the sum of the intensity of each pixel in the tail/ head multiplied by its distance from the centre.

\section{Reverse Transcriptase-Polymerase Chain Reaction (RT-PCR) Analysis}

RT-PCR was performed on control cells and cells treated with $100 \mu \mathrm{M} \mathrm{H}_{2} \mathrm{O}_{2}$ for respectively $15,30 \mathrm{~min}, 1,2,4,6,8,10$, and $20 \mathrm{~h}$ to detect the expression of genes involved in the apoptotic pathway, DNA base excision repair (BER) pathway and in free radical scavenging. Total RNA was extracted [Chromczynski and Sacchi, 1987] and $1 \mu \mathrm{g}$ RNA was reverse transcribed by M-MLV Reverse Transcriptase (Gibco BRL-Life Technologies) in the conditions suggested. The synthesized cDNAs were diluted 1:500.

PCR was performed in a $10 \mu \mathrm{l}$ reaction mixture containing $1 \mu \mathrm{l}$ of cDNA, 10X PCR Buffer II, $1.25 \mathrm{mM} \mathrm{MgCl}_{2}, 200 \mu \mathrm{M}$ dNTPs, 0.125 U of AmpliTaq Gold DNA Polymerase (PerkinElmer Corporation). All the samples were amplified for each target gene and GAPDH. PCR was performed for each gene under identical conditions. The ethidium bromide signals for GAPDH showed uniform intensity; hence the modulation in the expression or absence of any changes in the expression of target genes are fully supported and justified. Amplifications were performed, after an initial denaturation at $95^{\circ} \mathrm{C}$ for $12 \mathrm{~min}$, for the above specified number of cycles according to the following regime: denaturation at $94^{\circ} \mathrm{C}$ for 30 sec, annealing at the above specified degrees for $30 \mathrm{sec}$ and extension at $72^{\circ} \mathrm{C}$ for $30 \mathrm{sec}$.

The primer sequences and annealing temperatures were as follows:

$\begin{aligned} \mathrm{Cu} / \mathrm{Zn} \text {-SOD: } & \text { upper } 5^{\prime} \text {-GAGCAGAAGGAAA- } \\ & \text { GTAATG-3' } 55^{\circ} \mathrm{C}, 32 \text { cycles) } \\ & \text { lower 5'-AGCAGGTAACAGAT- } \\ & \text { GAGT-3' }\end{aligned}$


GPX:

upper 5'-CGCACTCTCCAGCC-

TTTTC- $3^{\prime}\left(59^{\circ} \mathrm{C}, 30\right.$ cycles $)$

lower 5'-ACCGTTCACCTCGCA-

CTTC-3

CAT: upper 5'-TCTGGAGAAGTGCGGAGATT- $3^{\prime}\left(58^{\circ} \mathrm{C}, 36\right.$ cycles) lower $5^{\prime}$ - TCTTCATCCAGTGATGAGCG-3'

OGG-1: $\quad$ upper 5'-CTGCCTTCTGGACAATCTTT-3' (58 $\mathrm{C}, 34$ cycles) lower 5'-TGACCCGCCCTGTTCTTC-3'

HAP-1: upper $5^{\prime}$-GCCGCAAAGAAAAATGAC- $3^{\prime}\left(55^{\circ} \mathrm{C}, 36\right.$ cycles)

lower $5^{\prime}$-TAGGGTGATAGGACAGTG-3'

NTH-1: $\quad$ upper $\quad 5^{\prime}$-GCGGGGGTGTAGGGAGGA- $3^{\prime}\left(58^{\circ} \mathrm{C}, 34\right.$ cycles)

lower 5'-CGGGCAGAGGGCTTGGTT-3'

Bcl-2: $\quad$ upper $5^{\prime}$-CCTGATCATTGGGGAAGCTGG- $3^{\prime}\left(59^{\circ} \mathrm{C}, 36\right.$ cycles) lower 5'-TGGGTAACTCTAGCCTTCCT-3'

Fas: $\quad$ upper 5 - CAAAGCCCATTTTTCTTCCA- $3^{\prime}\left(58^{\circ} \mathrm{C}, 32\right.$ cycles) lower 5'- GACAAAGCCACCCCAAGTTA-3'

p53: $\quad$ upper 5'-TGTTCACTTGTGCCCTGAT- $3^{\prime}\left(58^{\circ} \mathrm{C}, 36\right.$ cycles)

lower 5'-CAGCCCTGTCGTCTCTCC-3'

Caspase-8: upper 5'-TCATTTTGAGATCAAGCCCC-3' $\left(59^{\circ} \mathrm{C}, 28\right.$ cycles)

lower 5'-GCAGAAAGTCAGCCTCATCC-3'

GAPDH: upper 5'-CCATGGAGAAGGCTGGGG-3' (54 ${ }^{\circ} \mathrm{C}$ for 23 cycles) lower 5'-CAAAGTTGTCATGGATGACC-3'

\section{RESULTS}

\section{Kinetics of Induction of Apoptosis and} Necrosis by $\mathrm{H}_{2} \mathrm{O}_{2}$

The early response gene jun is known to be transcribed in response to $\mathrm{H}_{2} \mathrm{O}_{2}$ oxidative stress [Beiqing et al., 1996]. The optimum $\mathrm{H}_{2} \mathrm{O}_{2}$ concentration needed for generating stress responses from the cells was determined by assaying for jun activation by Northern blotting. $\mathrm{H}_{2} \mathrm{O}_{2}$ at $100 \mu \mathrm{M}$ for $2 \mathrm{~h}$ induced jun activation (data not shown). Therefore, this

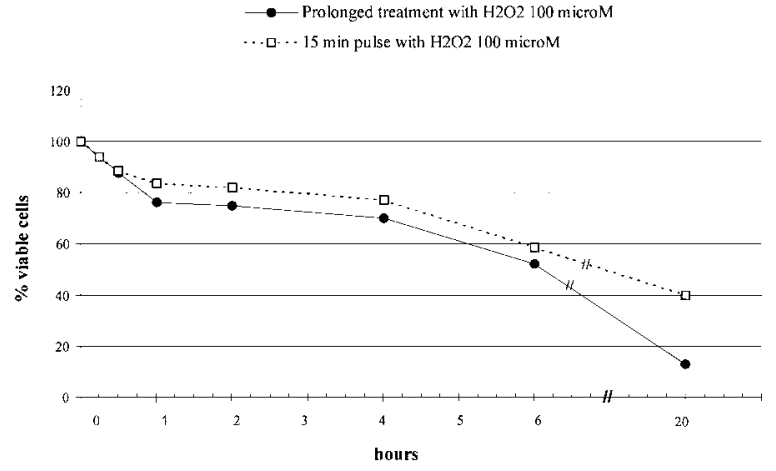

Fig. 1. The kinetics of induction of necrosis by $\mathrm{H}_{2} \mathrm{O}_{2}$ in Jurkat cells. Data are presented from a typical experiment (of three replicate experiments in each case) in which cells were treated with $\mathrm{H}_{2} \mathrm{O}_{2}$ for $15 \mathrm{~min}$ and then maintained in normal medium for duration of the experiment $(-\square-)$, or exposed continuously ( $-1-$ ). The viability of cells was monitored at the various time points.

was chosen as the working concentration for the following experiments.

Cellular damage caused by $100 \mu \mathrm{M} \mathrm{H}_{2} \mathrm{O}_{2}$ was examined over a $20 \mathrm{~h}$ time frame. Apoptosis and necrosis were assayed and both processes were induced by a short stimulus of $15 \mathrm{~min}$. Parallel experiments were performed on cells primed with $\mathrm{H}_{2} \mathrm{O}_{2}$ for 15 min or kept in $\mathrm{H}_{2} \mathrm{O}_{2}$ for the full $20 \mathrm{~h}$ duration. Necrotic changes were noticed at $1 \mathrm{~h}$ from commencement of treatment and increased gradually until cell viability drops to between $55-60 \%$ at the $6 \mathrm{~h}$ point. In the $6-20 \mathrm{~h}$ phase cell viability decreases by a further $20 \%$ in 15 min treated cells and by $30 \%$ in cells under continuous treatment (Fig. 1). Apoptosis was detected after about $4 \mathrm{~h}$. There was a small increase up to the $6 \mathrm{~h}$ point, but then rose sharply, from 8 to $24 \%$ in cells subjected to oxidative stress for $15 \mathrm{~min}$ and from 10 to $40 \%$ in cells exposed continuously to $\mathrm{H}_{2} \mathrm{O}_{2}$ (Fig. 2).

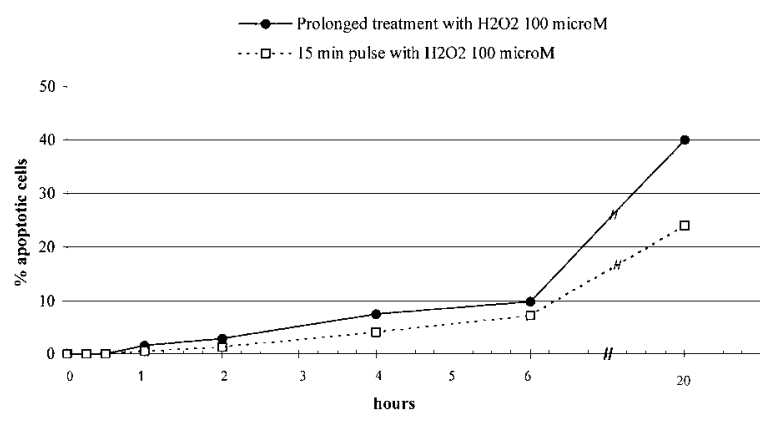

Fig. 2. The kinetics of induction of apoptosis by $\mathrm{H}_{2} \mathrm{O}_{2}$, in cells exposed to oxidative stress for $15 \mathrm{~min}(-\square-)$ or continuously $(-\mathbf{0}-)$. Apoptosis was measured at the various time points over the $20 \mathrm{~h}$ time frame. The graphs represent data from one of three replicate experiments. 


\section{Modulation of Expression of Genes in the Apoptotic Pathway}

In the present experiments attention was focused upon the expression of p53, Bcl-2, Caspase-8, and Fas genes, following exposure of the cells to oxidative stress. Bcl-2 expression was down regulated beginning with the $2 \mathrm{~h}$ exposure point up to and including the $10 \mathrm{~h}$ point. The expression of Caspase- 8 was also down regulated during the same time points. The down regulation of these genes roughly coincided with necrotic changes. Both $\mathrm{Bcl}-2$ and Caspase- 8 were up regulated at $20 \mathrm{~h}$. This is the phase in which apoptosis shows a marked increase. There was no detectable change in the expression of the Fas and p53 genes (Fig. 3).

\section{DNA Damage Repair During Oxidative Stress}

DNA damage was evaluated by the comet assay in Jurkat cells maintained in $\mathrm{H}_{2} \mathrm{O}_{2}$ for
20 h. As shown in Figure 4, the oxidative treatment produced marked DNA damage as compared with control cells, at the 15 min point in treatment. A gradual repair of DNA damage was apparent over the $20 \mathrm{~h}$ period. However, the repair process did not continue to reach control levels. We recognise, however, that there is no possibility of distinguishing if DNA breaks are caused by free radicals or by nucleases involved in apoptotic process since the Comet assay detects apoptotic nuclei as cells with damaged DNA [Gopalakrishna and Khar, 1995].

In contrast, when cells were placed in fresh medium after 15 min $\mathrm{H}_{2} \mathrm{O}_{2}$ treatment, the repair of DNA damage was more rapid, and control levels were reached in $\sim 1 \mathrm{~h}$ (Fig. 5). Particularly, at each experimental time, a lower level of damage was found in cells in normal fresh medium as compared with their counterparts maintained for the same time in medium containing $\mathrm{H}_{2} \mathrm{O}_{2}$. After $2 \mathrm{~h}$ in fresh medium,

$B c l-2$

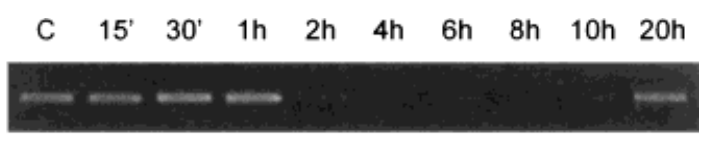

\section{Caspase-8}

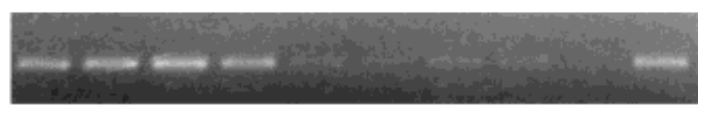

Fas

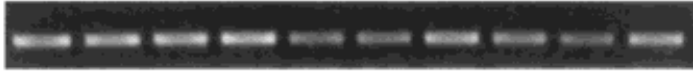

p53

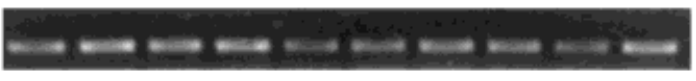

$G A P D H$

Fig. 3. Expression of $B C l-2$, Caspase-8, p53, and Fas genes in Jurkat cells treated with $\mathrm{H}_{2} \mathrm{O}_{2}$ for durations as shown. The target genes and GAPDH were amplified under conditions described in Materials and Methods. The signal densities of the house-

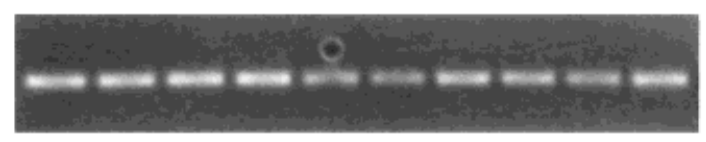

keeping gene GAPDH were uniform, in marked contrast with the intensity of signals of the target genes. The figure illustrates the marked down regulation of $\mathrm{BCl}-2$ and Caspase- 8 , but not of Fas and $p 53$. 


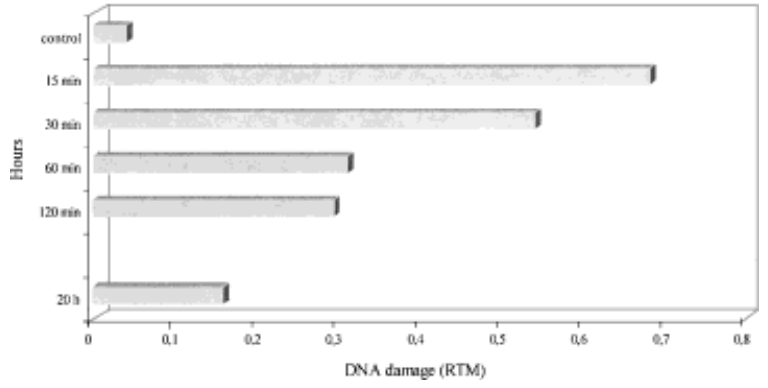

Fig. 4. Profile of DNA damage and repair in cells, based on the measurement of 50 cells at each time point, exposed to $\mathrm{H}_{2} \mathrm{O}_{2}$ continuously for $20 \mathrm{~h}$. DNA damage was measured at the time intervals shown.

cells had a relative tail moment of 0.08 compared with 0.30 obtained in cells maintained in the same medium plus $\mathrm{H}_{2} \mathrm{O}_{2}$.

These results suggest that cell defences (DNA repairing and ROS scavenging enzymes) can cope adequately with DNA damaging action of $\mathrm{H}_{2} \mathrm{O}_{2}$, but if $\mathrm{H}_{2} \mathrm{O}_{2}$ is present in the medium, damaging action of ROS continues over the experimental period and partially hampering DNA repair.

\section{Expression of Genes Involved in DNA Damage Repair and ROS Scavenging}

A major source of damage to DNA is the oxidation of bases and sugars by reaction with ROS [Demple and Harrison, 1994]; these species react at numerous sites on DNA. Among the most important lesions are modified base, apurinic/apyrimidinic sites and DNA strand breaks with atypical termini. Repair of these lesions requires that the damaged base is excised by the combined action of a DNA glycosylase, an AP endonuclease and a $3^{\prime}$

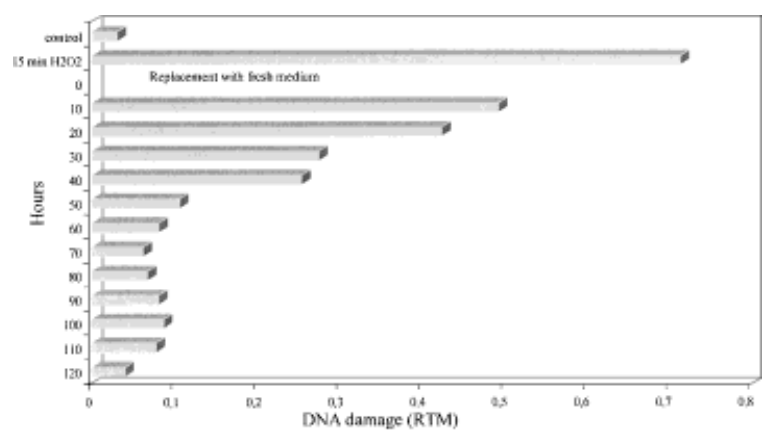

Fig. 5. DNA damage and repair in cells, based on the measurement of 50 cells in each time point, exposed to $\mathrm{H}_{2} \mathrm{O}_{2}$ for $15 \mathrm{~min}$ and then washed and maintained in normal medium for $2 \mathrm{~h}$. The levels of DNA damage were measured at $10 \mathrm{~min}$ intervals.
A

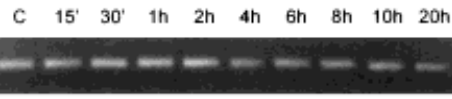

OGG-1

NTH-1

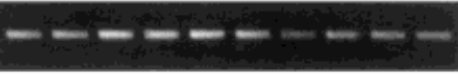

$H A P-1$

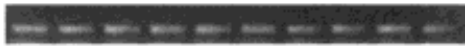

GAPDH

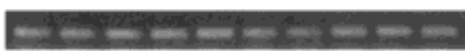

B

C $15^{\circ} 30^{\circ}$ in $2 \mathrm{~h} \quad 4 \mathrm{~h} \quad 6 \mathrm{~h}$ 8h $10 \mathrm{~h} \quad 20 \mathrm{~h}$

\section{$\mathrm{Zn} / \mathrm{Cu}-\mathrm{SOD}$}

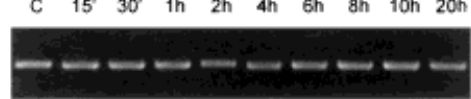

GPX

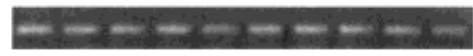

CAT

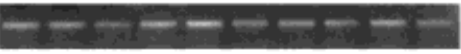

GAPDH

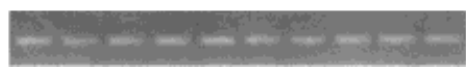

Fig. 6. Expression of $O G G-1, N T H-1$, and $H A P-1$ (panel A) or $\mathrm{Zn} / \mathrm{Cu}-\mathrm{SOD}, G P X$, and CAT genes (panel B) in Jurkat cells treated with $\mathrm{H}_{2} \mathrm{O}_{2}$ for durations as shown. The figure illustrates the uniform intensity of the signals of the target genes as well as of GAPDH, indicating that the expression of the target genes had not altered during the experiment.

phosphodiesterase. Therefore the levels of expression of $N T H-1, H A P-1$, and $O G G-1$ genes, which are known to be involved with the repair process [Robson and Hickson, 1991; Rosenquist et al., 1997; Imai et al., 1998], were evaluated at different experimental times and no differences were detected (Fig. 6A). Similarly, the expression of $C A T$ (catalase), $\mathrm{Zn} / \mathrm{Cu} S O D$, the cytoplasmic form of superoxide dismutase [Lieman-Hurwitz et al., 1982], and GPX (glutathione peroxidase) [Chada et al., 1990] genes, whose products are involved in free radicals scavenging, was not modulated for the whole experimental time (Fig. 6B).

\section{DISCUSSION}

In the present study the Jurkat cell line has been employed as model for the study of oxidative signalling leading to apoptosis and necrosis. The choice of this model has been 
dictated by the fact that their membrane markers strongly resemble those found in normal T-lymphocytes [Konikova et al., 1992]. $\mathrm{H}_{2} \mathrm{O}_{2}$ has been used as oxidative stimulus since it can permeate the plasma membrane and can be converted intracellularly into more reactive oxygen intermediates.

There is now a consensus view that apoptosis of cells is mediated by the activation of specific signal transduction pathways. A number of distinct pathways of transduction of the apoptosis signal have been identified. The p53 suppressor gene controls cell cycle progression at $\mathrm{G}_{1}-\mathrm{S}$ and $\mathrm{G}_{2}-\mathrm{M}$ checkpoints and also acts as a tumor suppressor. It is known to induce apoptosis in response to a variety of stress signals, including oxidative stress [Ko and Prives, 1996; Giaccia and Kastan, 1998]. This could be resulting from the induction and accumulation of $p 53$ in response to apoptotic signals [Brockhaus and Brune, 1999]. The effect of p53 is reversible, if the apoptotic signal is withdrawn in the early stage of the process [Geske et al., 2000]. However, in the experiments described here, apoptosis and necrosis continued to occur in spite of the removal of $\mathrm{H}_{2} \mathrm{O}_{2}$ from the culture medium. Wild-type p53 induces apoptosis by activating caspases [Schuler et al., 2000]. Therefore, both necrosis and apoptosis occurring in the present experimental conditions seems to be independent of $p 53$.

The Bcl-2 family of gene are well known modulators of the process of apoptosis. The promotion of apoptosis appears to be mediated by the activation of caspases. In contrast, Bcl-2 also seems to be able to down regulate caspase activity [see Sherbet and Lakshmi, 1997; Sherbet, 2001]. $\mathrm{H}_{2} \mathrm{O}_{2}$ activates both necrotic and apoptotic pathways of cell death, as recognised previously [Watson et al., 1995]. The necrosis pathway is activated first and this is characterised by down regulation of both $\mathrm{Bcl}-2$ and Caspase-8. Nonetheless, apoptosis does occur in this phase and, possibly, this is a consequence of the abrogation of the protective effect of $\mathrm{Bcl}-2$, but this is achieved by other means than the suppression of caspase activity. Another possible pathway of $\mathrm{Bcl}-2$ signalling is believed to be its ability to suppress lipid peroxidation and the suppression of the generation of free radicals [Hockenberry et al., 1993]. $\mathrm{H}_{2} \mathrm{O}_{2}$ not only generates ROS, but this is normally associated with increased expression of $C A T$ and $C u$ / $Z n S O D$ as well as $M n-S O D$. The present experiments seem to exclude this possibility, since the expression of genes coding for antioxidant enzyme was unaffected, even though $\mathrm{Bcl}-2$ expression was down regulated upon exposure of the cells to $\mathrm{H}_{2} \mathrm{O}_{2}$. However, in the light of the non-activation of DNA repair genes and the survival of a majority of cells, one cannot exclude the possibility that other scavenging cellular proteins such as polyamines could contribute to the overall lack of modulation of expression of DNA repair genes and those coding for free radical scavenging proteins.

ROS are powerful inducers of p53 and Pani et al. [2000] have shown that it negatively regulates $M n S O D$. It is possible that p53 similarly negatively regulates $\mathrm{Cu} / \mathrm{ZnSOD}$. Brockhaus and Brune [1999] found that nitric oxide-induced apoptosis involves the induction and accumulation of $\mathrm{p} 53$, and furthermore that $\mathrm{Cu} / \mathrm{ZnSOD}$ protects the cells from apoptosis.

The activation of caspases has been implicated in Fas receptor-mediated apoptosis of activated lymphocytes. Fas is a member of the TNF family of proteins. It is a transmembrane protein. When the Fas receptor is bound by its ligand, the target cells undergo apoptosis [Nagata and Golstein, 1995; Nagata, 1997]. The occupancy of the Fas receptor leads to the activation of caspases and to the activation of down-stream proteases leading to DNA fragmentation [see Sherbet, 2001].

Perara and Waldmann [1998] showed that the spontaneous apoptosis of peripheral blood monocytes could be reversed by the supplementation of the growth medium with serum and growth factors. This is accompanied by a downregulation of caspase-8. Furthermore, caspase deficiency makes certain Jurkat cell lines resistant to Fas-mediated apoptosis [Kawahara et al., 1998]. In the present experiments, although the expression of Fas seems to be unaltered, that of Caspase- 8 is markedly down regulated. This is another indication that the apoptosis signal imparted by $\mathrm{H}_{2} \mathrm{O}_{2}$ in the early phase is not transduced via the caspase pathway. This is compatible with the view expressed by some that caspases may not be an invariable feature of Fas-mediated induction of apoptosis [Kawahara et al., 1998; Zheng et al., 1998; Sherbet, 2001]. However, we note in this context that caspase- 8 activation might be involved mainly in ligand-induced apoptosis. In stress or chemically induced apoptosis, mitochondria are the site of signalling involving caspase- 9 , and in 
this case activation of caspase- 8 is delayed. The up-regulation of caspase- 8 could be due to a delayed activation of this type.

One must also consider the possibility that during the phase of stress when caspase- 8 is down regulated, other proteases might be involved. However, apoptosis picks up strongly in the late $(6-20 \mathrm{~h})$ phase of the experiment, and this is indeed accompanied by the up regulation of both Bcl-2 and Caspase- 8 genes. These findings are amenable to the interpretation of a possible change in the regulation of the apoptotic pathway. Furthermore, in the present series of experiments necrotic injury seems to precede apoptotic cell death. The increased commitment of cells to the apoptotic pathways seems to occur with the up regulation of $\mathrm{Bcl}-2$ and Caspase- 8 genes. The concomitant down regulation of both $\mathrm{Bcl}-2$ and Caspase- 8 could be a result of necrotic degradation. The up-regulation that occurs subsequently could be taking place in different cells, with $\mathrm{Bcl}-2$ being expressed in the surviving cell population.

As one would expect, DNA damage repair and apoptosis are related. A comparison of the kinetics shows that DNA damage repair is $\sim 6$ fold more efficient in cells exposed to $\mathrm{H}_{2} \mathrm{O}_{2}$ for periods of up to $1 \mathrm{~h}$ than in cells exposed to oxidative stress for periods between 2 to $20 \mathrm{~h}$. This suggests that the degree of apoptosis is related to the efficiency of DNA damage repair. There is an inverse relationship between these two features, and less efficient DNA damage repair is conducive to apoptosis. This is compatible with the recent findings of Szumiel et al. [2000], who showed that the differential induction of apoptosis occurring in two LY lymphoma sub-lines was attributable mainly to the differences in their ability to repair DNA damage.

It has been shown that oxidative damage results in the activation of the DNA damage repair enzyme poly (ADP-ribose) polymerase (PARP) [Latour et al., 2000]. Furthermore, PARP inhibitors accentuate the necrotic changes occurring in the wake of oxidant injury [Filipovic et al., 1999]. Watson et al. [1995] have shown that inhibitors of PARP can inhibit necrosis but not apoptosis. The necrotic phase seems to last until the DNA damage repair reaches virtual control levels, and at this point genes that control the apoptotic pathway appear to come into play. Thus the pathways of cell death signalling are not only exquisitely controlled but the switching of cells from one pathway to another might depend upon the nature of the cell death signal.

\section{ACKNOWLEDGMENTS}

We thank Professor Giovanni Tredici and Dr. Gabriella Niccolini for the use of the fluorescence microscope and their helpful advice.

\section{REFERENCES}

Beiqing L, Chen M, Whisler RL. 1996. Sublethal levels of oxidative stress stimulate transcriptional activation of cjun and suppress IL-2 promoter activation in Jurkat T cells. J Immunol 157:160-169.

Brockhaus F, Brune B. 1999. Over-expression of $\mathrm{Cu} / \mathrm{Zn}$ superoxide dismutase protects RAW 264.7 macrophages against nitric oxide cytotoxicity. Biochem J 338:295-303.

Buttke TM, Sandstrom PA. 1995. Redox regulation of programmed cell death in lymphocytes. Free Radical Res 22:389-397.

Chada S, Le Beau MM, Casey L, Newburger PE. 1990. Isolation and chromosomal localization of the human glutathione peroxidase gene. Genomics 6:268-271.

Chomczynski P, Sacchi N. 1987. Single-step method of RNA isolation by acid guanidinium thiocyanate-phenol-chloroform extraction. Anal Biochem 162:156-159.

Cooke MS, Mistry N, Wood C, Herbert KE, Lunec J. 1997. Immunogenicity of DNA damaged by reactive oxygen species-implications for anti-DNA antibodies in Lupus. Free Rad Biol Med 22:151-159.

Dandona P, Thusu K, Cook S, Snyder B, Makowski J, Amstrong D, Nicotera T. 1996. Oxidative damage to DNA in Diabetes mellitus. Lancet 347:444-445.

Demple B, Harrison L. 1994. Repair of oxidative damage to DNA: enzymology and biology. Annu Rev Biochem 63:915-948.

Dobmeyer TS, Findhammer S, Dobmeyer JM, Klein SA, Raffel B, Hoelzer D, Helm EB, Kabelizt D, Rossol R. 1997. Ex vivo induction of apoptosis in lymphocytes is mediated by oxidative stress: role for lymphocyte loss in HIV infection. Free Rad Biol Med 22:775-785.

Duthie SJ, Ma A, Ross MA, Collins AR. 1996. Antioxidant supplementation decreases oxidative DNA damage in human lymphocytes. Cancer Res 56:1291-1295.

Filipovic DM, Meng XM, Reeves WB. 1999. Inhibition of PARP prevents oxidant-induced necrosis but not apoptosis in LLC-PK1 cells. Am J Physiol-Renal Physiol 46:F428-F436.

Frenkel K, Khasak D, Karkoszka J, Shupack J, Stiller M. 1992. Enhanced antibody titres to an oxidized DNA base in inflammatory and neoplastic diseases. Exp Dermatol 1:242-247.

Geske FJ, Nelson AC, Lieberman R, Strange R, Sun T, Gerschenson LE. 2000. DNA repair is activated in early stage of p53-induced apoptosis. Cell Death Differentiation 7:393-401.

Giaccia AJ, Kastan MB. 1998. The complexity of p53 modulation. Emerging patterns from divergent signals. Genes Dev 12:2973-2983.

Gopalakrishna P, Khar A. 1995. Comet assay to measure DNA damage in apoptotic cells. J Biochem Biophys Meth 30:69-73. 
Goppelt-Strube M, Resch K. 1987. Polyunsaturated fatty acids are enriched in the plasma membranes of mitogenstimulated T-lymphocytes. Biochim Biophys Acta 904: $22-28$.

Hockenberry DM, Oltvai ZN, Yin XM, Lilliman CL, Korsmeyer SJ. 1993. Bcl-2 functions in an antioxidant pathway to prevent apoptosis. Cell 75:241-251.

Imai K, Sarker AH, Akiyama K, Ikeda S, Yao M, Tsutsui K, Shohmori T, Seki S. 1998. Genomic structure and sequence of a human homologue (NTHL1/NTH1) of Escherichia coli endonuclease III with those of the adjacent parts of TSC2 and SLC9A3R2 genes. Gene 222:287-295.

Kawahara A, Ohsawa Y, Matsumura H, Uchiyama Y, Nagata S. 1998. Caspase-independent cell killing by Fasassociated protein with death domain. J Cell Biol 143: 1353-1360.

Ko LJ, Prives C. 1996. P53, puzzles and paradigm. Genes Dev 10:1054-1072.

Konikova E, Babusikova O, Kusenda J, Glasova M. 1992. Detection of cytoplasmic and surface membrane markers in cells of some human haematopoietic cell lines. Neoplasma 39:337-342.

Latour I, Leunda-Casi A, Denef JF, Calderon PB. 2000. Activation of poly (ADP-ribose) polymerase in rat hepatocytes does not contribute to their cell death by oxidative stress. Exp Cell Res 254:173-179.

Lieber MR. 1998. Pathological and physiological doublestrand breaks: roles in cancer, aging, and the immune system. Am J Pathol 153:1323-1332.

Lieman-Hurwitz J, Dafni N, Lavie V, Groner Y. 1982. Human cytoplasmic superoxide dismutase cDNA clone: a probe for studying the molecular biology of Down syndrome. Proc Natl Acad Sci USA 79:2808-2811.

McAllister-Sistilli CG, Caggiula AR, Knopf S, Rose CA, Miller AL, Donny EC. 1998. The effects of nicotine on the immune system. Psychoneuroendocrinol 23:175-187.

Nagata S. 1997. Apoptosis by death factor. Cell 88:355365.

Nagata S, Golstein P. 1995. The Fas death factor. Science 267:1449-1456.

Pani G, Bedogni B, Anzevino R, Colavitti R, Palazzotti B, Borello S, Galeotti T. 2000. Deregulated manganese superzoxide dismutase expression and resistance to oxidative injury in p53-deficient cells. Cancer Res 60 4654-4660.

Perara LP, Waldmann TA. 1998. Activation of human monocytes induces differential resistance to apoptosis with rapid down regulation of caspase-8/FLICE. Proc Natl Acad Sci USA 95:14308-14313.

Riso P, Pinder A, Santangelo A, Porrini M. 1999. Does tomato consumption effectively increase the resistance of lymphocyte DNA to oxidative damage? Am J Clin Nutr 69:712-719.

Robson CN, Hickson ID. 1991. Isolation of cDNA clones encoding a human apurinic/apyrimidinic endonuclease that corrects DNA repair and mutagenesis defects in $E$. coli xth (exonuclease III) mutants. Nucleic Acids Res 19:5519-5523.

Rosenquist TA, Zharkov DO, Grollman AP. 1997. Cloning and characterization of a mammalian 8-oxoguanine DNA glycosylase. Proc Natl Acad Sci USA 94:7429-7434.

Schuler M, Bossy-Wetzel E, Goldstein JC, Fitzgerald P, Green DR. 2000. p53 induces apoptosis by caspase activation through mitochondrial cytochrome c release. J Biol Chem 275:7337-7342.

Sherbet GV. 2001. Calcium Signalling in Cancer. Boca Raton, FL, USA, CRC Press. p 169-176.

Sherbet GV, Lakshmi MS. 1997. The Genetics of Cancer. London: Academic Press. p 76-90.

Suzuki N, Wakisaka S, Takeba Y, Mihara S, Sakane T. 1999. Effects of cigarette smoking on Fas/Fas ligand expression of human lymphocytes. Cell Immunol 192: $48-53$.

Szumiel I, Jaworska A, Kapiszewska M, John A, Gradzka I, Sochanowicz B. 2000. Differential induction of apoptosis in x-irradiated L5178Y sub-lines bearing p53 mutation. Radiation Environ Biophys 39:33-40.

Watson AJM, Askew JN, Benson RSP. 1995. Poly (adenosine diphosphate ribose) polymerase inhibition prevents necrosis induced by $\mathrm{H}_{2} \mathrm{O}_{2}$ but not apoptosis. Gastroenterology 109:472-482.

Zheng TS, Schosser SF, Dao T, Hingorani R, Crispe IN, Boyer JI, Flavell RA. 1998. Caspase-3 controls both cytoplasmic and nuclear events associated with Fasmediated apoptosis in vivo. Proc Natl Acad Sci USA 95: 13618-13623. 